\title{
The "Holy Houses" of the SS. Annunziata in Terra di Lavoro
}

\author{
Raffaela Fiorillo ${ }^{1}$ \\ ${ }^{1}$ Department of Architecture and Industrial Design - Università degli Studi della Campania "Luigi Vanvitelli" \\ Aversa (CE), Italy \\ Email: raffaela.fiorillo@unicampania.it
}

\begin{abstract}
The main objective of the study is to verify the existence of specific architectural models and on this basis, subsequently establish the possible transmission channels of the architectural types, as well as the architects involved and the workers engaged in the service of the Confraternities of A.G.P.

This paper constitues an anticipation of a large study on the territory in the Terra di Lavoro and in particular of the foundations attributed to the Institute of the Lay Confraternity of Ave Gratia Plena (A.G.P), churches consecrated to the Santissima Annunziata. At first analysis, the territory appears chatacterized by the presence of several and extensive monastic complexes dedicated to the SS. Annunziata, which, following precisely the conventual model, are usually set based on a structure often endowed by cloister, sometimes from a hospital and a pawn shop. The recurrence of these structures suggests that, despite being of lay Confraternities, the foundations of the A.G.P. behave similary contemporary monastic orders, with general rules and similar types of architecture. This first reflection was reflected in the documented participation of the same architects to build headquartes employees by the Institute. Characteristic of the buildings that belong to confraternities of Ave Gratia Plena turned out to be the localization at the margins of the urban mesh. A feature of the existing buildings of the Ave Grazia Plena Confraternities was found to be the location at the edge of the urban jets, which are often separated by a wall that defines the foundation perimeter of the confraternites. The main objective of the study is to verify the existence of specific architectural models and on this basis, subsequently establish the possible transmission channels of the architectural types, as well as the architects involved and the workers engaged in the service of the Confraternities of A.G.P.
\end{abstract}

(C) 2019 The Authors. Published by IEREK press. This is an open access article under the CC BY license (https://creativecommons.org/licenses/by/4.0/).

Keywords

Architecture; brotherhoods; territory.

\section{The development of the city of Capua}

The development of Capua was strongly conditioned by the presence of the Volturno river which was one of the preferential routes for sorting goods already in Roman times, that is when Capua, the current SaMaria Capua Vetere, represented the center of political life, the river port of Casilinum, today's Capua, the center of economic- commercial activities, and the area of the Sanctuary of Diana Tifatina which represented the center of worship (Mingione, Ruberti, Strumia \& Vigliotti, 2004).

Over the centuries, Capua has always been an extremely important site both in strategic and military terms, and because it is dominant over a completely flat area, easily controllable, and because it is located in the bend of the Volturno river, which marked the border between the garrisoned urban fabric on three sides, and the surrounding 
area. The urban layout of the medieval Capua has followed the design already defined by the Lombards (856-1062) developing along two road directions: one towards the north and the other towards the east.

A cartographic image of the city was executed by Francesco Cassiano de Silva between 1695 and 1705 and presented differences with respect to the representation of Il Regno di Napoli in prospettiva of 1702, text by Giovan Battista Pacichelli. In the representation of Cassiano it can be seen that the urban circle is perfected and the drawing of the river's course is more distant from the true route of the Volturno river (Amirante, 2005).

The extra-urban territory is simplified and made more homogeneous with respect to the representation provided by Pacichelli where the building is represented in a disorderly way, but the city, despite its confused representation, shows compact construction, with buildings with two-storey high buildings (Pane \& Filangieri,1990).

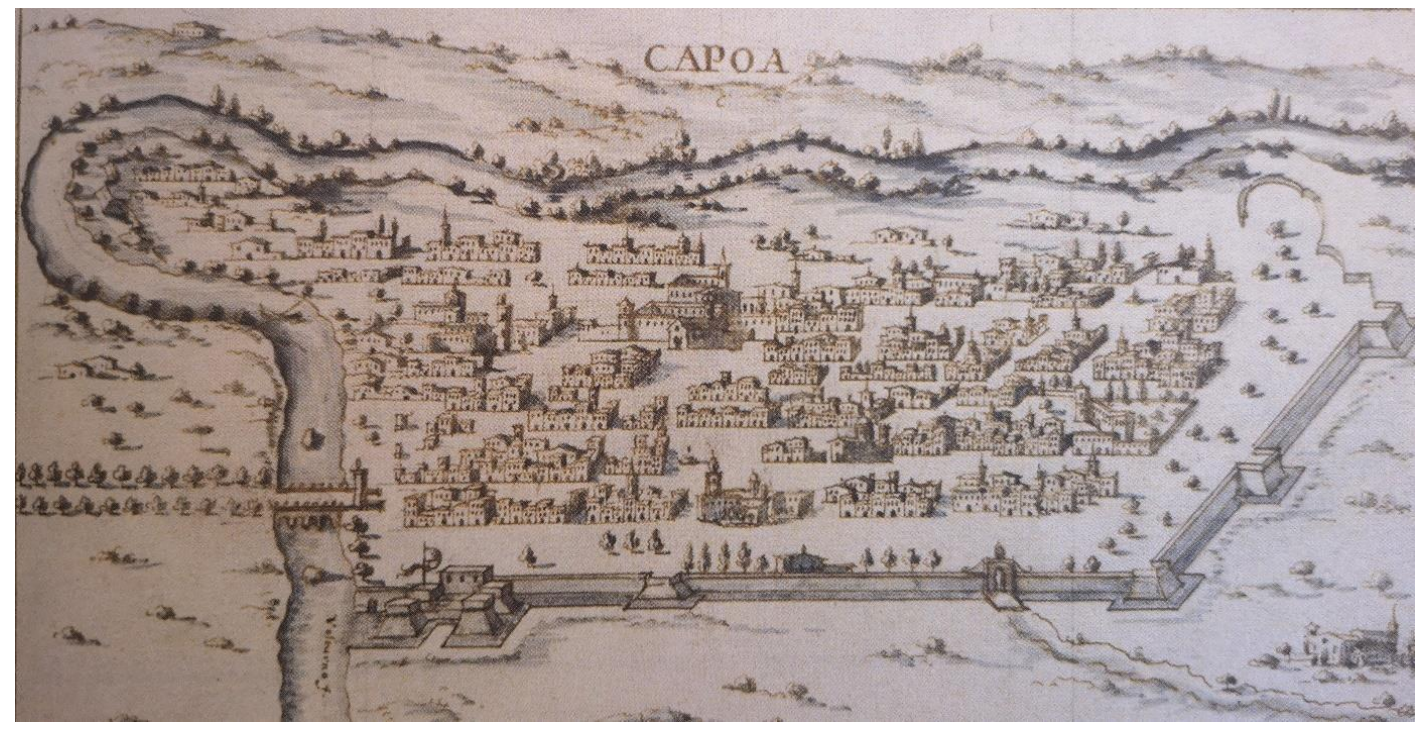

Figure 1. Cartographic image of the city was executed by Francesco Cassiano de Silva.

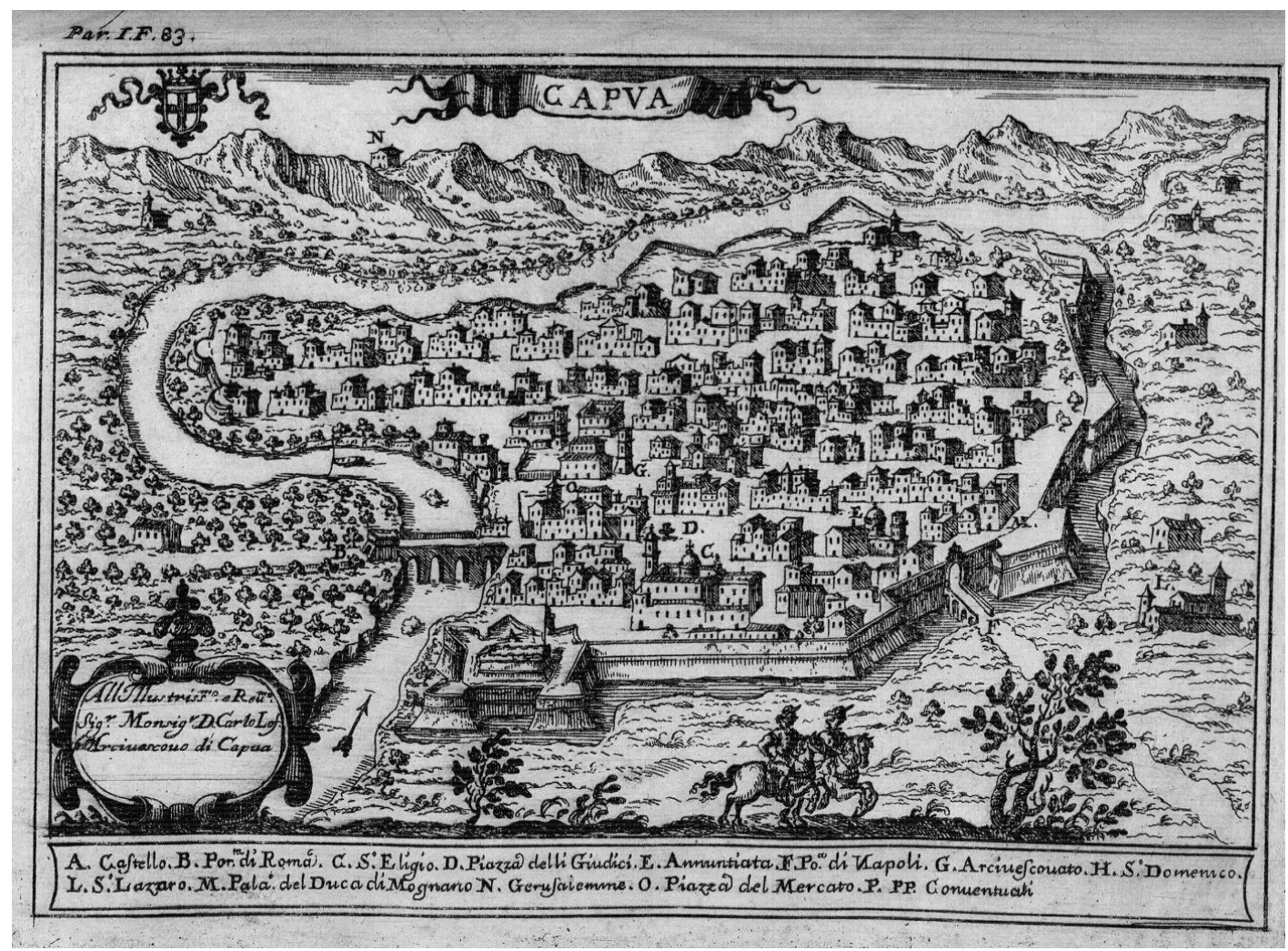

Figure 2. Perspective of Capua town, from the book by Pacichelli (1703). 


\section{The church of the Annunziata of Capua.}

The present Church of the Annunciation was built on a primitive Angevin Church founded in the reign of Charles II of Anjou (Garofano Venosta, 1966).

In a manuscript preserved in the library of the Museo Campano, the Public Beneficial Administrative Commission of the City of Capua compiles a register of the possessions of the Holy House in which it is noted that in 1461, at the request of King Ferdinand of Aragon, Pope Pius II granted the title of parish to the church with the care of souls of the Hospital and Retreat. In 1521 the fourteenth-century church was unsafe and it was decided to build a new Church. The research carried out by Lucia Giorgi has allowed us to follow the story in detail (Giorgi, 1990). The construction of the present church began in 1531 according to the model that will come from Rome. In an essay we learn that the wooden model of the church and the bell tower (1531) was made by Master Battista Fiorentino who lives in Rome. Subsequently the Governors of the Annunziata decided not to make the master Battista model anymore, but a project written in 1538 by a master Architect of Naples, identifiable with Giovan Francesco Di Palma (De Rosa, 2001). The hypothesis is endorsed by various analogies that can be found between the Capuan church and some religious buildings made by Giovanni Donadio, known as il Mormando; according to Giorgi, the articulation of the main façade of the Annunziata di Capua refers to some sixteenth-century Neapolitan churches. The successive phases of work saw the participation of the architect Capuano Ambrogio Attendolo called in 1556 to direct the construction site.

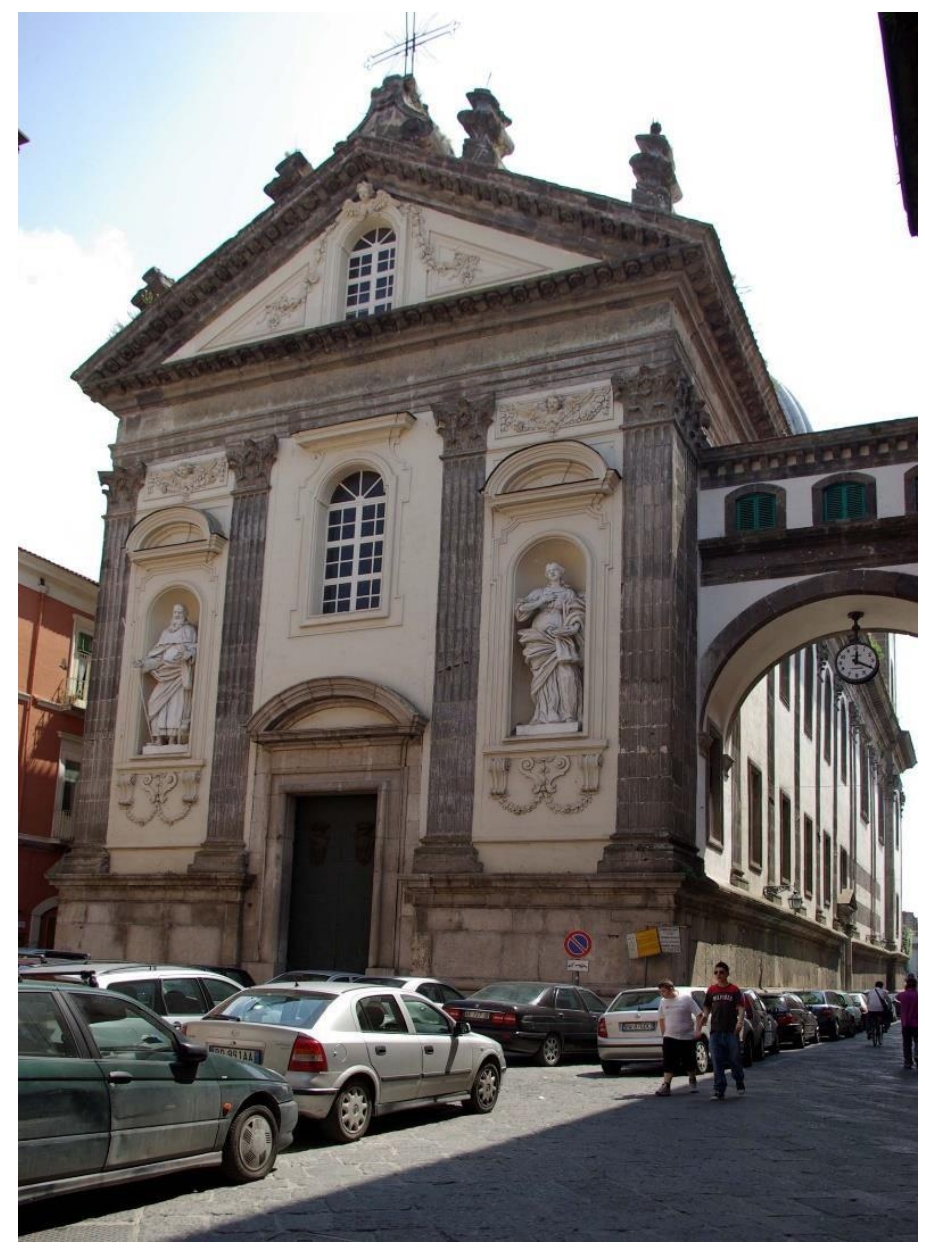

Figure 3. Facade of the church of the SS. Annunziata

With the passing of the years the support structures of the dome of the church were damaged so much that the five city administrators, the Commissioner of the Royal Roads, the engineers Ambrogio Attendolo and Giacomo Frisone with the foremen who presented a detailed report of the solution from to adapt. The structures that presented instability had to be strengthened and the technicians interviewed suggested that before building the lantern, they would build a chain of oak beams and build the round-headed dome. The solutions proposed by the Frisone were probably not accepted since they were subsequently asked to consult the Attendolo again 
In 1583 the construction of the church was almost complete, so much so that the master carpenters Antonello d'Isca, Giovan Battista Porfido and Giovan Angelo Manso were called to make a quote for the coverage of the church. They proposed the construction of a coffered (tempiatura) similar to that of the churches of the Annunziata and the Holy Spirit of Naples. The construction of the church probably ended in 1588. Between 1616 and 1619 baroque interventions were made in the church, evident also in the stucco decorations on the facade.

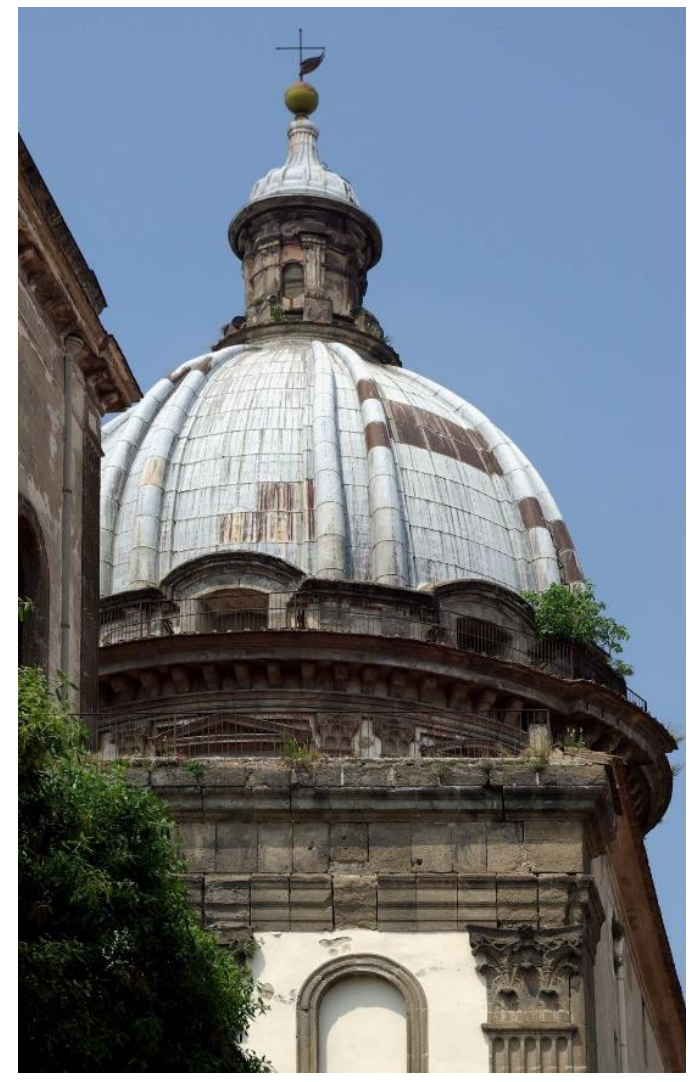

Figure 4. Detail of the dome

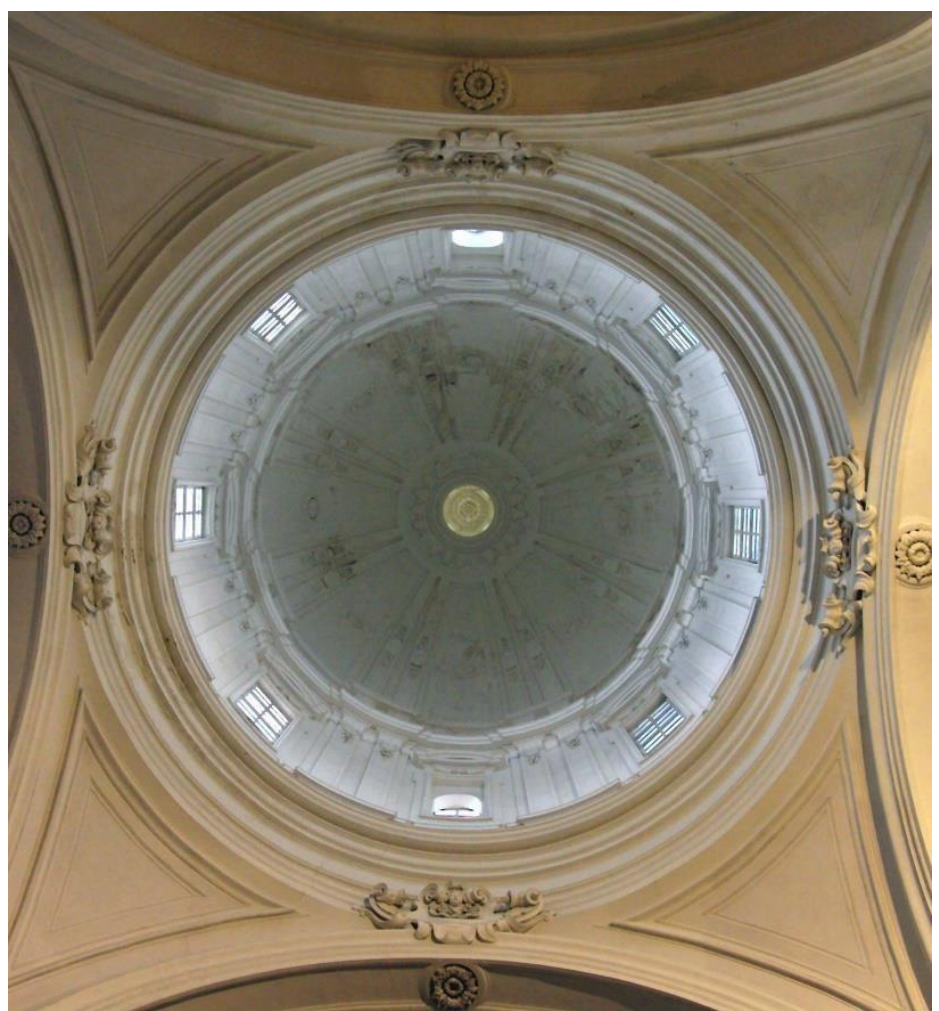

Figure 5. Cover dome of the presbytery 


\section{The new eighteenth century phase.}

A new phase of work was recorded starting from the middle of the 18th century; in 1755 works were completed to complete the altars and the wooden coffered and new works were estimated in the dome, in the sacristy and in the conservatory with the participation of illustrious Neapolitan architects: Mario Gioffredo, Ferdinando Fuga, Francesco Gasperi, Giovanni Bonpiede and Francesco Collecini (Serraglio, 2001). The period during which the direction of the work was entrusted to the architect Collecini, from 20 July 1791 to December 1804 when he died, can be divided into two parts: from 91 to 1997 the dormitories and the factory of the new Conservatory, after the 1999 the damages suffered by the dome were repaired during the French occupation of the city. The works of the new Conservatory were concluded in 1797 when the payments were authorized by the engineer Iannotta. The conservatory has a square plan with a central courtyard, on the sides of which there is a portico. It kept its function until 1861, when it was used as a barracks. Today it houses the municipal offices. The church of the SS. Annunziata was damaged by bombing in 1943, and was later consolidated and restored. The 1987 restoration highlighted the internal architectural stratification covered by Baroque stucco decorations. The plant has a single nave, preceded by an internal atrium, on which the choir is placed, and has five chapels on each side, above which is the corridor for guests of the nearby hospital. The inlaid and carved wooden choir originally belonged to the Church of San Benedetto di Capua. It consists of two orders; in the first, opened in 4 points to give access to the second, benches with backs decorated with shaped cornices can be noted. In the second order there are 23 stalls with armrests.

The backs are divided by pilasters carved with foliage, grotesque figures etc... and concluded by a shell-shaped niche.

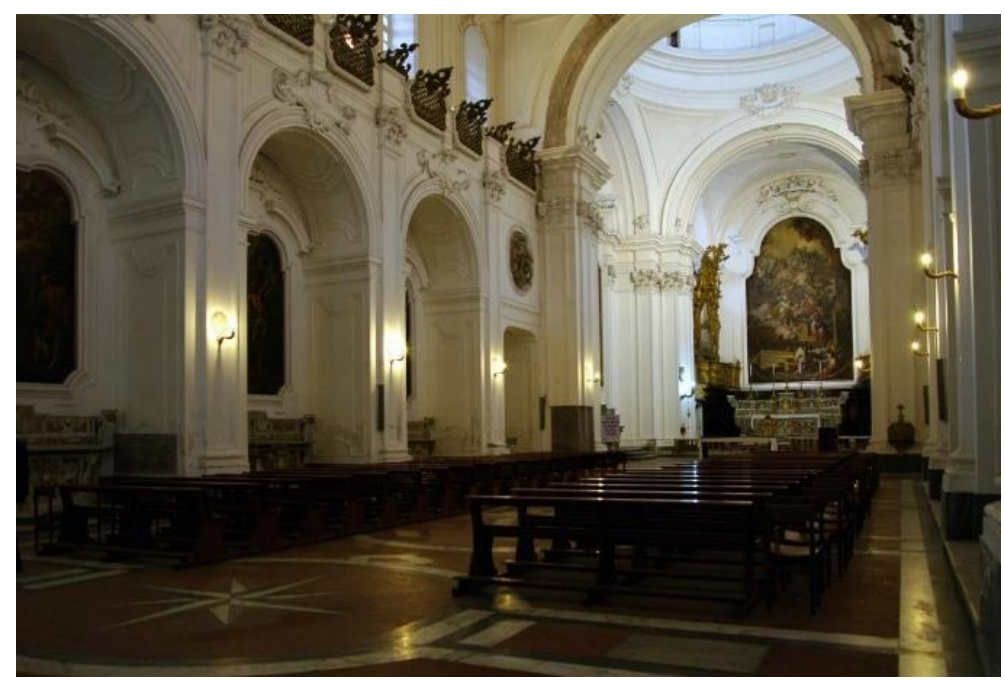

Figure 6. View towards the altar.

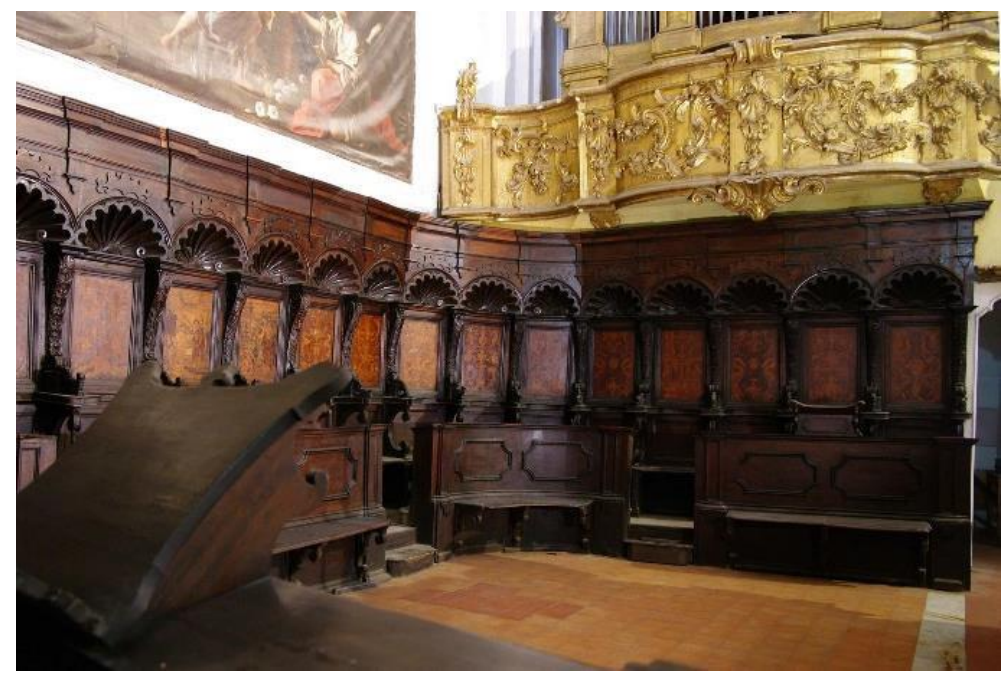

Figure 7. Detail of the wooden choir 
The church on the façade has a Renaissance typology characterized by a high stone base, made with bare materials from the Campano amphitheater; above the basement there is a giant order with four fluted Corinthian pilasters supporting an entablature, with a jutting cornice that divides the façade into three bays: the central one has an arched window, while the side ones are characterized by niches with statues of Saint Anthony and Saint Lucia; among the capitals there are decorations with heads of putti. The portal has a curved tympanum at the top.

At the top there is a large tympanum with an arched window decorated with floral motifs and four pinnacles on the roof. Next to the church, on Corso Appio, there is an arch-shaped passage that constitutes the ancient access for the nuns from the adjoining convent to the church's gallery. The side elevation is also marked by twin Corinthian pilasters, on a high base, which separate the lowered arched windows on pilasters with internal panels.

The church is flanked by a double-order bell tower; the first characterized by Corinthian pilasters separated from the second by a large cornice (Pane \& Filangieri,1990). Today, the entire structure is affected by abundant rain infiltrations, it is in a state of total abandonment with worrying signs of slowing down which have made it necessary to prohibit the transit of pedestrians and the parking of vehicles in the adjacent areas.

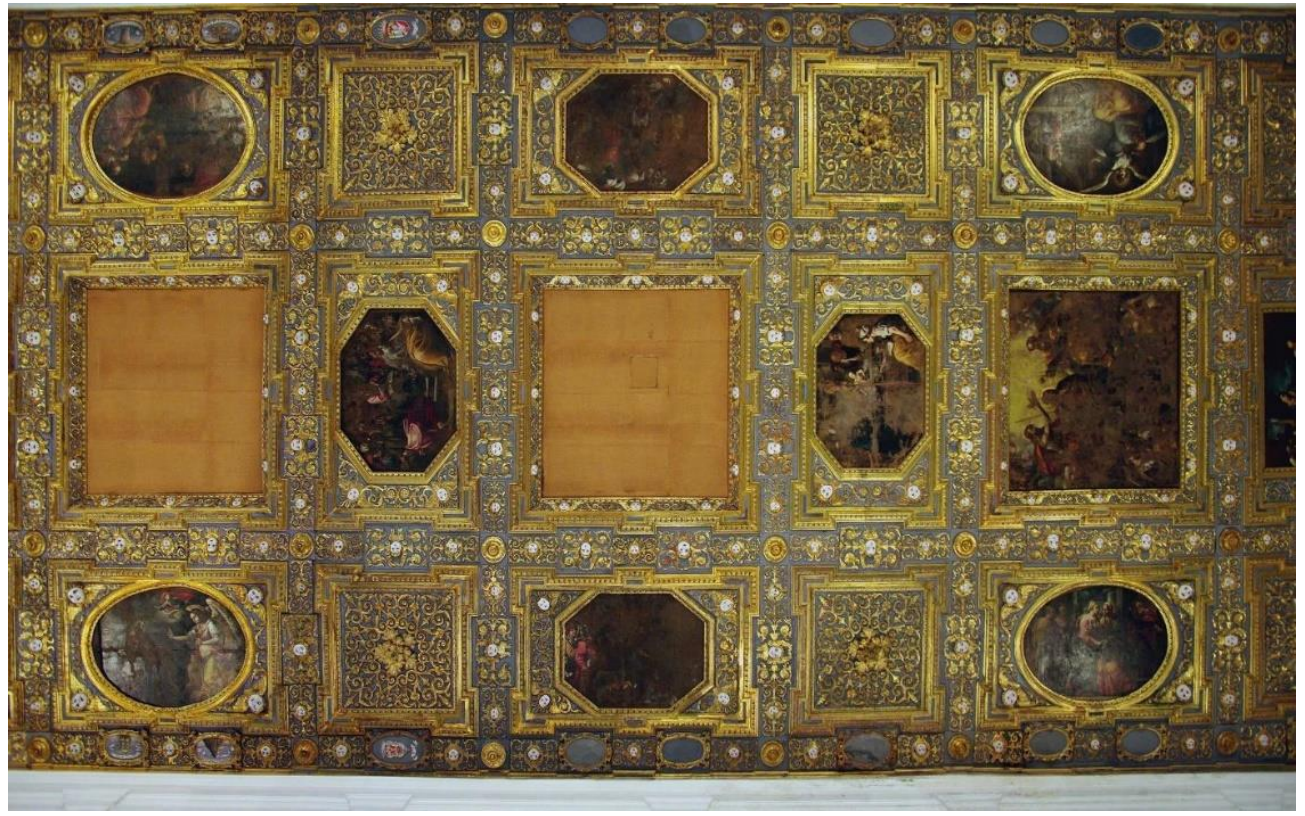

Figure 8. Ceiling. church of the SS. Annunziata.

\section{Conclusions}

The Holy House of the Annunziata of Capua, is one of the oldest religious-run charitable institutions and is one of the most important and remarkable religious complexes in the city. Its foundation was contemporary or a little closer to that of the Holy House of Naples between 1318 and 1320, perhaps the first established in Campania, to which it has always been closely linked for its activities. From the study and the documents it has been possible to reconstruct the history, the function and the historical-artistic events of these important religious complexes.

\section{References}

Mingione, E., Ruberti, D., Strumia, S. \& Vigliotti, M. (2004). Cartografia storica e sistemi GIS per lo studio dell'evoluzione dei caratteri fisici Amirante, G. \& Pessolano, M. R. (2005). Immagini di Napoli e del Regno. Le raccolte di Francesco Cassiano de Silva. Napoli.

Pane, G. \& Filangieri A. (1990). Capua. Architettura e Arte, catalogo delle opere, (Vol. II). Napoli.

Garofano-Venosta, F. (1966). Antichi ospedali di Capua. Aversa.

De Rosa, D. (2001). In Capys n 34, La chiesa dell'Annunziata di Capua. Contributo storiografico e nuovi documenti,(pp.131 - 148),Capua.

Giorgi, L. (1990). Architettura religiosa a Capua. I complessi della SS. Annunziata, S. Maria e S. Giovanni delle Dame Monache. Roma.

Serraglio, R. (2001). Interventi settecenteschi per la santa casa dell'Annunziata di Capua. In A. Gambardella (Ed.) In Atti del convegno internazionale di studi "Ferdinando Fuga"1699-1999 Roma, Napoli, Palermo, (p.358). Napoli Edizioni Scientifiche italiane. 